Journal of Tropical Industrial Agriculture
and Rural Development
https://jurnal.unej.ac.id/index.php/JTIARD

\title{
The effect of pillen seed storage time and application of humic acid on the growth of tobacco seedlings (Nicotiana tabacum L.)
}

\author{
Yogi Farid Fadilah and Usmadi \\ Study Program of Agrotechnology, Faculty of Agriculture, University of Jember Jl. Kalimantan 37, Kampus Tegal Boto, \\ Jember - 68121
}

\begin{abstract}
Tobacco is one of the seeds that can be stored for a specified period. Seed storage is one of the ways in maintaining the viability of the seeds to meet the needs of the next planting period. Pillen seed technology has developed where in addition to increasing the size of seeds can improve the quality of seeds. Kaolin in pillen has an $\mathrm{Al}$ content which is suspected if absorbed by plants will inhibit the growth of tobacco seeds. Giving humic acid is expected to be able to play a role in binding $\mathrm{Al}$ so that the level of $\mathrm{Al}$ content in the soil can be lowered so as not to cause toxins to plants. This study aimed to determine the effect of pillen seed storage and the application of humic acid on the growth of tobacco seedlings. This study used the factorial of complete randomized design (RAL) $2 \times 3$. The first factor of the concentration of humic acid consisted of without humic acid $0 \mathrm{ml} / 1$ and liquid humic acid $6 \mathrm{ml} / \mathrm{l}$. The second factor for the shelf life of the top seeds is 3,8 , and 13 years. Humic acid concentration of $6 \mathrm{ml}$ could support the growth of the tobacco seedlings.
\end{abstract}

Keywords: tobacco seeds, seeds saving, humid acid

\section{ARTICLE INFO \\ Corresponding Author: \\ Usmadi \\ Usmadi04@gmail.com}

Received: 03 March 2020

Accepted: 23 May 2020

Published: 10 June 2020

DOI: 10.19184/jtiard.v1i1.16414

How to cite:

Fadilah YF, Usmadi (2020). The effect of pillen seed storage time and application of humic acid on the growth of tobacco seedlings (Nicotiana tabacum L.). J. Trop. Ind. Agric. Rural Dev. 1(1): 27-32

\section{INTRODUCTION}

One of the factors that determined the productivity and quality of tobacco is the planting material used. To anticipate the unavailability of seeds during the growing season, seed storage is often carried out in the crop cultivation practice. Tobacco seed is one of the seeds that can be stored in a certain period and is commonly conducted in cultivation practices (Yuniarti and Djaman, 2015). Storage of seeds is one of the efforts in maintaining seed viability within a certain period to maintain the condition of the seeds in good condition during the storage period, which is used to meet the needs of the next planting period. The use of seeds with low-quality results in the growth of seedlings produced is not optimal (Tefa, 2017).
Pillen seed is a way to improve the quality and viability of seeds by coating the seeds with certain ingredients. According to Sari et al. (2013), seed coating, besides easing the seed dispersal, can also function as a carrier of additives and improve seed viability. One problem that arises as a result of coating on seeds is $\mathrm{Al}$ (Aluminum) poisoning of seed sprouts. Al poisoning is assumed to be caused by the kaolin material used as a seed coating material known to have an Al-dd content of 1,20 me/100 $\mathrm{g}$ of soil in the $\mathrm{pH}$ range of 5,23 . The content of $\mathrm{Al}$ when absorbed by plants in large quantities will be toxic to tobacco seeds. Koesrini et al. (2015), in his study, explained that the high content of $\mathrm{Al}$ in kaolin inhibits root growth in soybean plants, thus affects the cell division and elongation in meristem areas of roots. The 
influence of high concentration of $\mathrm{Al}$ causing the formation of a layer that covers the epidermis at the tip of the root which causes stunted root growth and results in cell damage, especially around the root tip cells.

One effort to reduce the level of $\mathrm{Al}$ poisoning can be made by providing organic material. An example of organic material that can be used to reduce the level of $\mathrm{Al}$ poisoning is the addition of humic material. Providing humic acid can increase NO3-, SO4-. This compound can bind $\mathrm{Al} 3+$ by forming complex organic compounds (Firmansyah, 2010).

According to Wahyudi (2007), negatively charged humic acid will bind positively charged $\mathrm{Al}$; therefore, the $\mathrm{Al}$ content can be reduced. Based on these considerations, it is necessary to study the application of humic acid to assess the growth of tobacco seeds from pillen seeds that have undergone a storage period.

\section{MATERIAL AND METHOD}

\section{Experimental design}

The experiment was conducted on JulySeptember 2018 at the greenhouse of PT. Perkebunan Nusantara X Jember Tobacco Research. The experiment was arranged using a Completely Random Design (CRD) $2 \times 3$ with five replications. The first factor was the concentration of humic acid $(\mathrm{H})$ consisting of 2 levels, namely without humic acid (H0), liquid humic acid $6 \mathrm{ml} / \mathrm{l}$ (H1). The second factor was the duration of seed saving (S) consisting of seeds stored for three years (S1); Seeds stored for eight years (S2); Seeds stored for 13 years (S3). Data obtained from observations were analyzed using analysis of variance (ANOVA), if there was a significant difference, then it was continued with the Tukey's Honest Significant Difference test (HSD) at the 95\% confidence level.

\section{Preparation of pillen seed making media and pillen seed covering process}

The composition of pillen making media consisted of a mixture of kaolin and soil. A comparison of the composition used in this experiment was $400 \mathrm{~g}$ of kaolin: $100 \mathrm{~g}$ of soil. The process of seed coating begins with turning on the pillen machine with a rotation of $40-50 \mathrm{rpm}$, followed by inserting tobacco seeds that have undergone a storage period of 3,8 , and 13 years each of $3 \mathrm{~g}$ into the Molen Pillen machine. Tobacco seeds inside the molen machine were sprayed with seven sprays of distilled water, and then the seeds were sprinkled with the media little by little as much as three tablespoons adjusted according to the number of seeds entered. The activity was repeated every 15 minutes until the tobacco pillen seed size was around 1,7-2 $\mathrm{mm}$.

\section{Pillen seed content test}

Pillen seed content test was carried out on the petri dish by taking ten pillen seeds; then, the pillen seed was sprayed using aqua dest until it appeared that there was one scattered seed in one pillen seed.

\section{Seedling and seed planting media preparation}

The nursery media used in the experiment used TS-2 media. Ready media was inserted into a 27.5 $\times 36.6 \mathrm{~cm}$ pot tray with 63 holes, and each hole was filled with media until the pot tray's surface was level. Pillen seeds were then sown on the media till one pillen seed per one pot tray hole.

\section{Humic acid application and maintenance}

A 6 ml of humic acid was dissolved into 1 liter of water, then applied by watering the pot tray medium according to treatment at intervals of 2 days until the seeds were 15 days old. Media that had been planted with pillen seeds was then covered with black mulch plastic for six days to accelerate and increase the simultaneity of pillen seed germination. Maintenance includes watering, fertilizing, and controlling pests. Watering was done once a day using friar with 10-15 liters of water until the end of the nursery. Fertilization activities using NPK (16:16:16) fertilizer with a concentration of $1 \mathrm{~g} / \mathrm{l}$. Pest and disease control was conducted when there were symptoms of an OPT attack. Control was performed by spraying an insecticide made from active beta-cyfluthrin $25 \mathrm{~g} / \mathrm{l}$ with an application of $1,5 \mathrm{ml} / \mathrm{l}$. Meanwhile, weed control was conducted by weeding.

\section{Variable of observation}

Variables observed included: Germination, Seed stem height, seedling stem diameter, total leaf area, root length, root volume, root bulk 
weight, fresh seed weight, dry canopy weight, dry seed weight.

\section{RESULT AND DISCUSSION}

The summary results of the F-calculated values of all observational variables that have been made can be presented in Table 1. Based on the Fcalculated value of the 13 observed variables (Table 1) showed that the single factor of humic acid concentration $(\mathrm{H})$ showed significantly different results on seedling height, stem diameter, and root length then showed significantly different effects on the volume observation variable root, canopy fresh weight, and total fresh weight. The single factor of seed retention time (S) showed the results had a significant effect on seed germination. The interaction factor between the concentrations of humic acid $(\mathrm{H})$ with the storage period of the seed (S) showed results that did not affect all of the observed variables.

Table 1. Summary of F-Calculated based on analysis of variance in all experiment parameters

\begin{tabular}{|c|c|c|c|c|}
\hline \multirow[b]{2}{*}{$\stackrel{0}{z}$} & \multirow[b]{2}{*}{ 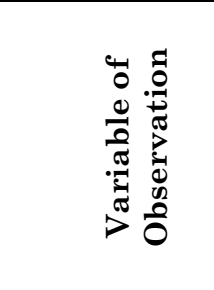 } & \multicolumn{3}{|c|}{ F- Calculated } \\
\hline & & 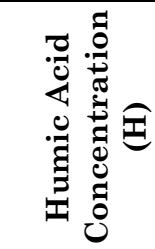 & 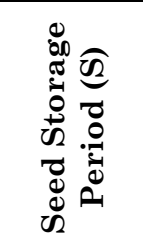 & 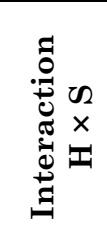 \\
\hline \multicolumn{5}{|c|}{ Parameter of Seed Viability } \\
\hline 1 & Germination & $0.98 \mathrm{tn}$ & $16.15 * *$ & $0.79 \mathrm{tn}$ \\
\hline \multicolumn{5}{|c|}{ Growth Parameter } \\
\hline \multirow[t]{2}{*}{1} & Seedling & & & \\
\hline & Height & $16.71 * *$ & $0.67 \mathrm{tn}$ & $0.24 \mathrm{tn}$ \\
\hline \multirow[t]{2}{*}{2} & Stem & & & \\
\hline & Diameter & $14.64 * *$ & $0.35 \mathrm{tn}$ & $0.23 \mathrm{tn}$ \\
\hline 3 & Total Leaves & $0.42 \operatorname{tn}$ & $0.83 \mathrm{tn}$ & $2.86 \mathrm{tn}$ \\
\hline 4 & Leaf Area & $0.09 \mathrm{tn}$ & $0.09 \mathrm{tn}$ & $0.10 \mathrm{tn}$ \\
\hline 5 & Root Height & $16.38 * *$ & $0.41 \mathrm{tn}$ & $0.48 \mathrm{tn}$ \\
\hline 6 & Rood Volume & $7.12 *$ & $0.07 \mathrm{tn}$ & $0.98 \mathrm{tn}$ \\
\hline \multirow[t]{2}{*}{7} & Canopy Fresh & & & \\
\hline & Weight & $4.52 *$ & $0.05 \mathrm{tn}$ & $0.13 \mathrm{tn}$ \\
\hline \multirow[t]{2}{*}{8} & Root Fresh & & & \\
\hline & Weight & $2.25 \mathrm{tn}$ & $1.74 \mathrm{tn}$ & $1.26 \mathrm{tn}$ \\
\hline \multirow[t]{2}{*}{9} & Total Fresh & & & \\
\hline & Weight & $5.35 *$ & $0.09 \mathrm{tn}$ & $0.56 \mathrm{tn}$ \\
\hline \multirow[t]{2}{*}{10} & Canopy Dry & & & \\
\hline & Weight & $0.21 \mathrm{tn}$ & $1.27 \mathrm{tn}$ & $0.01 \mathrm{tn}$ \\
\hline \multirow[t]{2}{*}{11} & Root Dry & & & \\
\hline & Weight & $0.10 \mathrm{tn}$ & $2.18 \mathrm{tn}$ & $0.80 \mathrm{tn}$ \\
\hline \multirow[t]{2}{*}{12} & Total Dry & & & \\
\hline & Weight & $0.21 \mathrm{tn}$ & $1.27 \mathrm{tn}$ & $0.01 \mathrm{tn}$ \\
\hline
\end{tabular}

Description: tn (insignificantly different), * (significantly different), and ** (very significantly different).

\section{Seed germination}

Tobacco seeds are orthodox seeds which have good storability with fairly low water content. According to Kincaid (1943), tobacco seeds stored in a dry state with the right media can last for ten years. The quality and viability of tobacco seeds can be determined through testing the seed germination. The results of the study (Figure 1) indicated that tobacco seeds after going through storage for up to 13 years are still able to meet the requirements as good seeds and meet the standards set by SNI of $85 \%$. The difference in the percentage of germination of each seed is thought to be due to the effect of differences in the content of food reserves owned by each group of seeds given that the harvest time of the three treatments is not concurrent, so environmental factors can also affect seed quality. According to Kolo and Tefa (2016), seeds that have high quality are seeds that have high viability and vigor. Factors that can affect the viability of the seed are the initial viability of the seed, the level of maturity of the seed at the beginning of the harvest, the environment before harvesting, and the environment during the seed storage period.

\section{Plant height}

The treatment of humic acid concentration had a very significant effect on plant height. The results (Figure 2) showed the difference in plant height produced in this study allegedly because the addition of humic acid can improve the physical, chemical, and biological properties of the soil and can contribute to providing nutrients available to plants. Nutrients that are absorbed by plants will be used later for metabolic processes that aim at the process of cell division and enlargement (Salisbury and Ross, 1992).

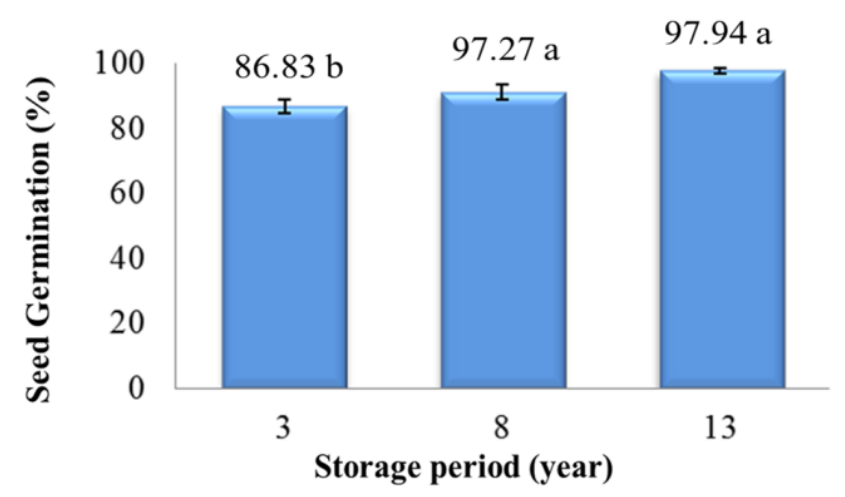

Figure 1. Effect of storage period on seed germination 


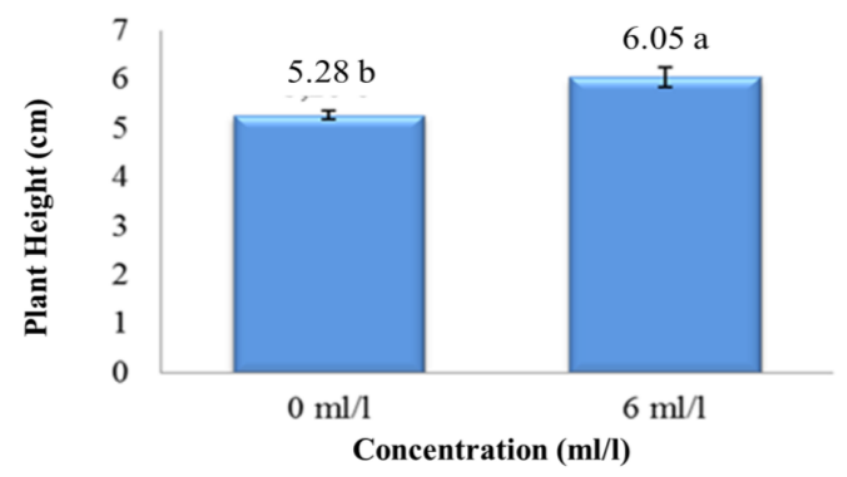

Figure 2. Effect of humic acid concentration on plant height

The addition of humic acid in tobacco nurseries can increase the average height of tobacco seedlings. These results followed the study of Jusmar (2014), which reported that the addition of humic acid to chili plants at a dose of $1,5 \mathrm{~g} / \mathrm{plant}$ was able to increase plant height by about $7 \mathrm{~cm}$ compared to control treatments. However, the high requirements of tobacco seedlings in the study experiment this time did not meet the criteria for seeds that were not ready for planting in the field. Requirements for the requirements for tobacco seeds that are ready for planting have a height of $\pm 10 \mathrm{~cm}$ (Budiman, 2010).

\section{Seedling diameter}

The treatment of humic acid concentration had a very significant effect on the diameter of the seedling stem. Providing humic acid is also able to support the growth of seedling stem diameter. The single factor of humic acid concentration had a very significant effect on the observation variables of tobacco seed stem diameter. The results of the study (Figure 3) showed that the application of humic acid in tobacco nursery media could increase the average diameter of tobacco seedling stems.

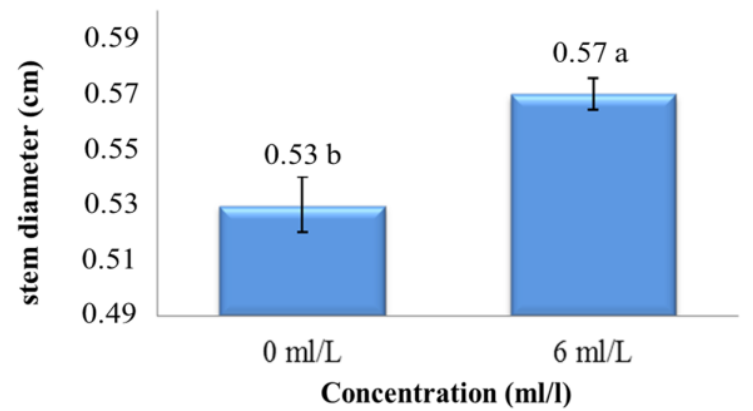

Figure 3. Effect of humic acid concentration on stem diameter of seedlings.
These results are consistent with the study results of Sembiring et al. (2015) the application of humic acid in oil palm seedlings can increase the diameter of palm oil humps around 1,26 cm at a dose of $50 \mathrm{~g} /$ polybag compared with control treatments. The addition of humic acid is thought to be able to increase the availability of nutrients, therefore capable of increasing plant growth. Nutrient absorption is an ion absorption process. Ion uptake by plants begins with the contact between the root surface with ions, then the ions move into the root cell then transported from cell to cell for metabolic processes (Wijaya, 2008).

\section{Root length}

The treatment of humic acid concentration had a very significant effect on the root length of the seedlings. According to Sutrian (1992), plants in the process of metabolism, especially cell division, will divide to form young tissue (meristem), including lateral meristems. The formation of plant tissue due to the influence of the process of cell division that is interconnected between plant tissue cells, so that plant tissue organs will experience additional sizes that affect the formation of roots, stems, and leaves. This is consistent with the results of the study, showing that the addition of humic acid has a very significant effect on the length of the roots of tobacco seeds (Figure 4).

Providing humic acid is thought to increase nutrient availability; therefore, it can support the root growth. The availability of sufficient nutrients can support the photosynthesis process. The photosynthesis process that runs optimally will produce energy; the energy produced is used for the process of cell division and elongation.

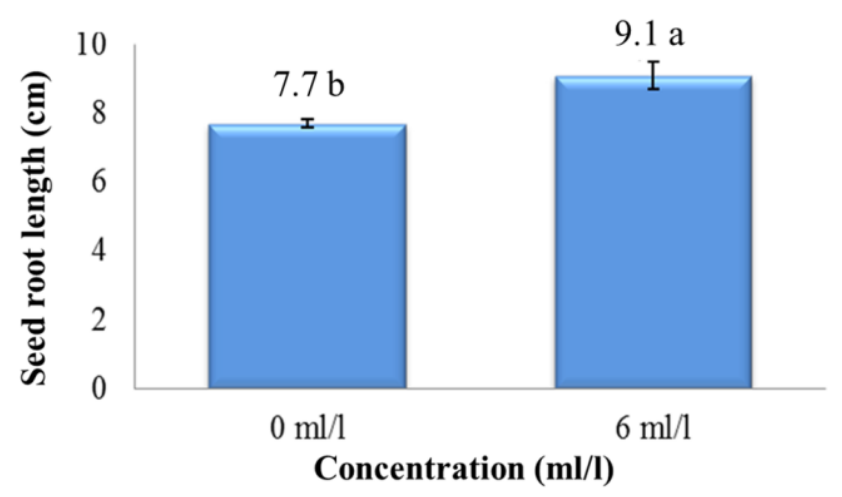

Figure 4. Effect of humic acid concentration on seed root length. 
In addition, the addition of humic acid directly affects the metabolic processes such as increased root respiration, protein synthesis, nucleic acids, increased photosynthesis rate, and permeability of the root membrane (Sarno and Fitria, 2012).

\section{Root volume}

The treatment of humic acid concentration had a significant influence on the volume of roots of tobacco seedlings.

Root growth which increases automatically will also affect the volume of root seeds produced. The results show that the addition of humic acid significantly affected the root volume of tobacco seedlings (Figure 5). Root volume reflects the ability of plants to absorb water and nutrients and metabolism in plant growth. Absorption of water and nutrients in sufficient quantities will increase root growth and branching. Humic acid from organic matter indirectly increases soil porosity through increased microorganism activity; therefore, it can stimulate root growth which will form loose soil structure and crumbs, this is a good soil physical condition for root growth media (Munawar, 2011). Crumb soil structure has high porosity and permeability so that water movement and air circulation can be freely moved, which will facilitate deeper root penetration. Thus the more the root lengthens, the root volume will also increase, hence the ability of plant nutrition absorption by the roots will also improve (Firdaus et al., 2013).

\section{Canopy fresh weight and total fresh weight}

The treatment of humic acid concentration had a significant effect on fresh canopy weight and total fresh weight but gave no significant impact on fresh root weight.

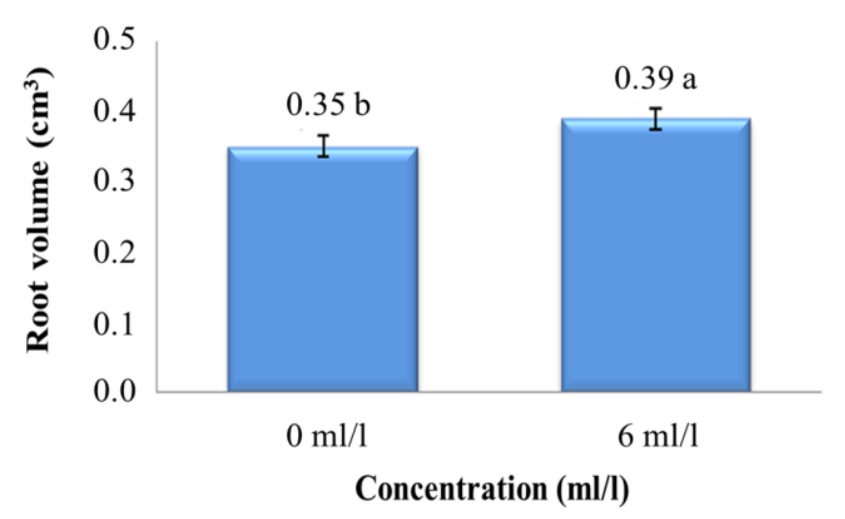

Figure 5. Effect of humic acid concentration on the root volume of seedlings

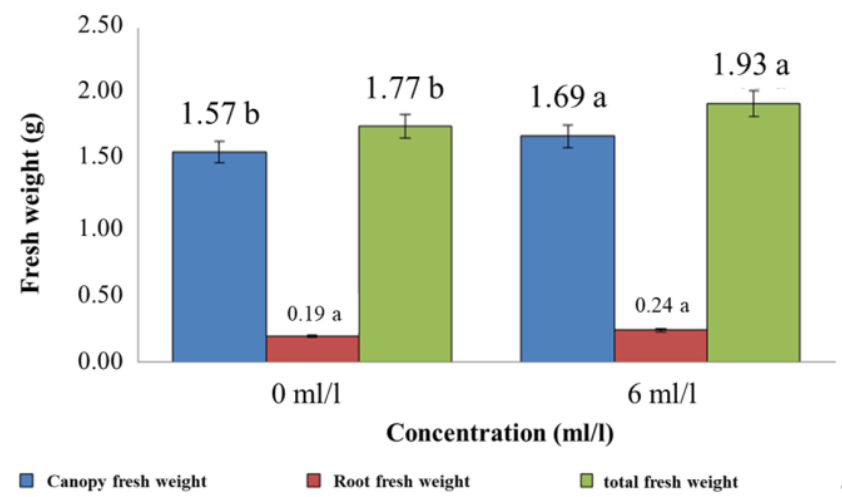

Figure 6. Effect of humic acid concentration on fresh canopy weight and total fresh weight

The results showed that the addition of humic acid could increase fresh canopy weight and total fresh weight (Figure 6). The fresh weight of the canopy is the weight of the plant after it is harvested before the plant withers and loses water; in addition, the fresh weight of the canopy is the total weight without roots which shows the results of plant metabolic activity. Fresh weight is the measurement result of plant biomass fresh weight of plant biomass as an accumulation of material produced during plant growth (Buntoro et al, 2014).

Nutrients and water absorbed by plants through the roots will affect plant growth. Accumulation of plant growth will affect the fresh weight of tobacco seedlings, the better the growth of tobacco seedlings, the higher the fresh weight of plants. The increase in canopy fresh weight and total fresh weight is thought to be due to nutrients needed by the seeds in sufficient quantities so that they can support the growth of tobacco. According to Haryadi, (2015), the increase in biomass is caused by plants absorbing water and nutrients well, thus spurring the development of plant organs in metabolic processes including photosynthetic activity which has increased, thus it affects the fresh weight of the tobacco seed canopy.

The increase in total fresh weight in (Figure 6) is thought to be due to an increase in plant height, stem diameter, root length, and root volume, therefore the addition of humic acid can increase the growth of plant organs to develop optimally resulted in the fresh weight of the plant also experiences increase. Plants that have optimal root growth will be more widely reach nutrients and water in the soil better so that plants will be used for photosynthesis and the results of photosynthesis are utilized by plants for growth 
and development, thus the fresh weight of plants will increase (Salisbury and Ross, 1992).

There was no significant interaction between the seed storage time and humic acid application on the growth of tobacco seedlings. The addition of humic acid concentration of $6 \mathrm{ml} / \mathrm{l}$ showed a significant effect on the growth variables of tobacco seedlings. Seeds that have been stored for 13 years still met the requirements based on the seed germination test.

\section{ACKNOWLEDGEMENT}

The author would like to thank the Research and Development Division of PTPN X Research and Development of Tobacco Research in Jember who had provided facilities in carrying out the study and scientific inputs, criticisms, and suggestions until this study was completed.

\section{REFERENCES}

Budiman H. 2013. Budidaya Tanaman Tembakau Kiat Menannam Tembakau Berkualitas Tinggi. Yogyakarta (ID). Pustaka Baru Pres.

Buntoro HB, R Rogomulyo, S Trisnowati. 2014. Pengaruh takaran pupuk kandang dan intensitas cahaya terhadap pertumbuhan dan hasil temu putih (Curcuma zedoaria L.). Vegetalika 3(4): 29-39.

Firdaus LN, S Wulandari, GD Mulyeni. 2013. Pertumbuhan akar tanaman karet pada tanah bekas tambang bauksit dengan aplikasi bahan organik. Biogenesis 10(1): 53-64.

Firmansyah AM. 2010. Respon tanaman terhadap aluminium. Agripura 6(2): 807-818.

Haryadi D, H Yetti, S Yoseva. 2015. Pengaruh pemberian beberapa jenis pupuk terhadap pertumbuhan dan produksi tanaman kailan (Brassica alboglabra L.). Jom Faperta 2(2): 1-10.

Jusmar AA. 2014. Pengaruh pemberian asam humat terhadap pertumbuhan dan hasil tanaman cabai (Capsicum annum L.). [Thesis] Fakultas Pertanian Padang, Indonesia: Universitas Tamansiswa Padang.
Kincaid RR. 1943. Effect of storage conditions on the viabilityof tobacco seed. Agricultural Research 67(10): 407-410.

Kolo E, A Tefa. 2016. Pengaruh kondisi simpan terhadap viabilitas dan vigor benih tomat (Lycopersicum esculentum Mill). Savana Cendana 1(3): 112-115.

Koesrini K, A Anwar, E Berlian. 2015. Penggunaan kapur dan varietas adaptif untuk meningkatkan hasil kedelai di lahan sulfat masam aktual. Berita Biologi, 14(2): 155-161.

Munawar A. 2011. Kesuburan Tanaman dan Nutrisi Tanaman. Bogor (ID): IPB Press.

Salisbury FB, CW Ross. 1992. Plant Physiology. Belmont (CA): Wadsworth Publishing.

Sari M, E Widajati, PR Asih. 2013. Seed coating sebagai pengganti fungsi polong pada penyimpanan benih kacang tanah. Agronomi Indonesia 41(3): 215-220.

Sarno S, E Fitria. 2012. Pengaruh aplikasi asam humat dan pupuk $\mathrm{n}$ terhadap pertumbuhan dan serapan $\mathrm{n}$ pada tanaman bayam (Amaranthus spp.). [Proceeding]. Lampung, Indonesia: SNSMAIP III.

Sembiring VJ, N Nelvia, AE Yulia. 2015. Pertumbuhan bibit kelapa sawit (Elaeis guineensis Jacq.) di pembibitan utama pada medium sub soil ultisol yang diberi asam humat dan kompos tandan kosong kelapa sawit. Agroteknologi 6(1): 25-32.

Sutrian Y. 1992. Pengantar Anatomi Tumbuh-Tumbuhan: Tentang Sel dan Jaringan. Jakarta (ID): Rineka Cipta.

Tefa A. 2017. Uji viabilitas dan vigor benih padi (Oryza sativa L.) selama penyimpanan pada tingkat kadar air yang berbeda. Pertanian Konservasi Lahan Kering 2 (3): $48-50$.

Wahyudi I. 2007. Peran asam humat dan fulfat dari kompos dalam detoksifikasi aluminium pada tanah masam. Buana Sains 7(2): 123-130.

Wijaya KA. 2008. Nutrisi Tanaman Sebagai Penentu Kualitas Hasil dan Resistensi Alami Tanaman. Jakarta(ID): Prestasi Pustaka.

Yuniarti N, DF Djaman. 2015. Teknik pengemasan yang tepat untuk mempertahankan viabilitas benih bakau (Rhizophora apiculata) selama penyimpanan. Biodiversitas Indonesia 1(6): 1438-1441. 